\title{
Journalists care about commercialization
}

\author{
BY INGELA WADBRING
}

\begin{abstract}
The aim of this study is to analyse journalists' view on commercialization over time. Since society as well as the media business have changed dramatically for the last few decades, it is reasonable to believe that opinion among journalists has changed as well. The study is based on three surveys conducted in Sweden between 1989 and 2011. The journalists are rather unanimous in their opinion, but workplaces differ. In general, the journalists feel that journalism is more commercialized today than before, and they find this to be negative.
\end{abstract}

\section{Introduction}

The concept of commercialization is frequently used in today's media debate. The media industry has become more commercialized than ever before, and the transformation is sometimes discussed in terms of a change from public-driven to marketdriven conditions (cf. Croteau and Hoynes, 2006). The concept could range from a general change in Western culture, to a requirement for media companies to be profit machines, and to sensationalize journalism (Wadbring, 2013). There are also a number of closely related concepts such as market-driven audience orientation and market management (e.g. Rolland, 2006, for an overview). It is thus a concept and phenomenon that can be used in several contexts, of which journalism is one. 
Journalists who embrace the ideal of journalism as a fourth estate are thus working in a more market-driven environment than ever before, and the interesting question is, to what extent and how they care about it. Are there any correlation between what happens in the media business, and what the employees in the media business perceive? In this paper, the aim is to analyse journalists' view on commercialization, and whether it has changed over time. The study is based on two research questions:

R01: What is journalists' opinion on commercialization, and has their opinion changed over time?

R02: Are journalists a homogenous group, or what can explain the journalists' opinions on commercialization?

As commercialization is a diffuse concept used in many different ways, I will start by giving an overview of how to analyse commercialization, and how the journalistic profession fits into this context. I will also discuss journalism as a profession, and possible explanatory factors for journalists' opinions. This is followed by a description of the design of the study, before I continue to the results and conclusions.

Worth mentioning is that Sweden got a commercial broadcast system rather late, at the beginning of the 1990's. Due to the political and media organizational structures, Sweden is sometimes characterized as part of the so-called Northern European or Democratic Corporatist Model, which is characterized by a strong press and public service, a high level of professionalism among journalists, and a state that supports, but does not control the media. Other countries with the same tradition are for example Austria, Norway and Germany. The commercialization process may look different in liberal countries like the United States, or in countries with a polarized, pluralist model like many of the Mediterranean countries (Hallin and Mancini, 2004).

\section{Commercialization at different levels}

There is a difference between talking about, for example, commercialized journalism, and commercial radio and TV channels 
in real terms and as connotations, as they touch on very different aspects of commercialization: content and financing form. To clarify the meaning of this, it is important to make sense of the concept, which can be done through, for example, categorization at different levels. It is then possible, and advisable, at least in part, to go beyond the subject of the media. Studies on commercialization can be categorized as follows (Wadbring, 2013):

Culture, i.e. our whole life sphere. Commercialization exists in all areas of society, of which the media area is one (McAllister 1996). Commercialization has generally increased over time, and it is often mentioned in terms of maximizing profit or in a purely ideological sense. Some examples, in addition to the media, are the school and university systems (Bok, 2003; Molnar, 1996; Thore, 2002), the emotional world such as, for example, care of our bodies (Hesse-Biber, 1996; Hochschild, 2003), art forms (Jensen, 1998), the tourist trade (Bodén and Rosenberg, 2004) and politics (Strömbäck, 2007).

The media market in general, where a general increase in competition means that the media need to try to maximize their audience - and their advertisers-and this applies to all media (e.g. McAllister, 1996). It also results in each individual media having a much smaller audience, in numerical terms (Beam, 2003; Hamilton, 2006; Picard, 2005, 2008). One reason for increased competition is the de-regulation process of the media industry. Public service channels also compete for an audience in the same market as companies with a more business-like approach. If the public service system is based on licence funds, and if the public service is not attractive enough, it is difficult for politicians to defend the financial systems of the licence (Djerf-Pierre, 2000; McQuail, 1985, 2005).

The companies, i.e. the single media companies. It can and has been discussed, whether, for example, ownership or an introduction to the stock exchange plays a part in the anticipated profit and dividend requirements of the companies (McManus, 1994; Picard, 2008). The discussion is, however, not new (Sylwan, 1906). It is open for discussion, whether jour- 
nalistic norms and values prevail in the editorial department, or if the marketing departments have become stronger at the expense of the editorial departments (Rolland, 2006). Other examples of commercialization features (and studies) that can be referred to company level are the division of functions within the companies, in other words, specialization of tasks (Nygren, 2008), and that the media companies listen to their audience and may have adapted to their audience differently than before (Andersson, 2009). At the same time, specialization, like customer and audience orientation, permeates all Western culture, including the media industry.

The journalists, i.e. persons employed by the media companies. There are many journalists on the boundary between journalism and entertainment, and between journalism and information activity (Ottosen, 2004). There are even those, who have almost become brands in their own right on the journalism market (Ottosen, 2004, Papathanassopoulos, 2001). The importance of professionalization in terms of commercialization of the journalistic profession is another subject for discussion (Fengler and Russ-Mohl, 2008). Professionalization has made journalists independent, but it has also given them similar values.

The product, i.e. journalism. Sometimes, research on commercialized journalism is based on a change at company or social level that is important to the journalistic content (McManus, 1994; Picard, 2008), more rarely this particular link is researched. There are, however, examples of such studies (e.g. Beam, 2003). The studies that consider or discuss the commercialization of journalism based on content are concerned with journalism that is personified, trivialized, dramatized, simplified, sensational, without credibility, etc. In short: It is about poor quality (e.g. McManus, 1994; Picard, 2005; Plasser, 2005).

The above categorization is one of probably many possible ways to try to understand, what the concept of commercialization can mean to the media and media studies. It is preferable to specify the current level and the causal connections that can 
really be commented on. In this study, the focus will be on the journalists, theoretically as well as empirically, but one underlying question is, if there is any correlation between changes in the media business and opinions among the employees. This will be discussed in the concluding section, but cannot be analysed empirically.

\section{The journalists as collective and individuals}

In terms of level (according to the above classification), the journalists find themselves between the market and the company, on the one hand, and journalism as content on the other. This means that they are potentially under pressure from the company management as well as the changing market itself. At the same time, they are a strong group within the media company, with similar values.

Researchers agree that the journalistic profession is not a profession in the traditional sense (Deuze, 2005; Singer, 2003; Wiik, 2010). The journalistic profession does not require formal education or competence, and no form of licence or certificate is issued. Since the beginning of the 1960s, however, Sweden has offered a journalist education, and the professional association is considerably older than that.

Studies show that, even though it is not a traditional profession, journalists are a homogeneous group in Sweden and abroad. Their ideals are similar, as is their perception of their work situation, even if differences between countries exist (Donsbach, 2004; Deuze, 2005; Hanitzsch et al., 2011). Instead of talking about a profession, one could talk about a semi-profession (Beam, 2003), or a common professional ideology (Deuze, 2005). This implies that one can expect the journalists view on commercialization to be rather similar, at least at a particular time. But even if journalists as a group have congruent opinions, their opinion may have changed in a similar way over time.

On the other hand, even if the journalists share an ideology, they are also individuals with individual features working under different structural conditions. Relevant factors could therefore 
be both structural and individual. Both types of factors are of importance in this study.

Examples of structural factors are, how journalists are geographically tied to what is being examined, namely financial pressure in the workplace and wanting to avoid conflicts (Berkowitz, 2007; O'Neill, 2008). In this study, one structural feature of importance is where journalists work. The work situation may play a part in what is culturally possible, and which resources are available. This is an explanatory approach at company level, according to the typology outlined above of different levels of commercialization. A simplified way of looking at commercialization is in terms of financing forms, and in this study, this will be used as an explanatory factor of the journalists' view on the commercialization of the media. Working in public service television, respectively, a single sold tabloid or a glossy magazine makes a difference, especially when it comes to commercialization. In one case, money is the means of good content, in the other, the content is the means of good financial results. This will be operationalized to an independent variable in terms of the financing form in the workplace.

Other researchers point at individual traits as explanatory factors for behaviours as well as attitudes (for an overview, see Donsbach, 2004). In this study, the journalists as individuals are empirically analysed in terms of traditional background factors: gender, age and ideological views - important components of social identity (Wiik, 2010). All of these have proven to be important, explanatory factors in studies of the Swedish journalistic profession. When it comes to the view on commercialization, which, to some extent, is an ideological issue, it is primarily the ideological view that ought to play a part. In this context, it is worth mentioning that the Swedish journalists stands ideologically to the left (Asp, 2007, 2012; cf. Andersson, 2009; Löfgren Nilsson, 2010; Wiik, 2010).

These general background factors are of course not just important to journalists, but apply to all analyses of human behaviour and attitudes. They concern our living conditions and social lives (Giddens, 2009). 


\section{Design of the study}

The analysis of the journalists' view on commercialization is based on three studies carried out at the Department of Journalism, Media and Communication at the University of Gothenburg, Sweden, in 1989, 2005 and 2011 (see Andersson, 2012). The population consists of members of the Swedish Union of Journalists (SJF), which is a combined professional and trade union that brings together the absolute majority of Sweden's practising journalists.

The sample has consisted of a representative sample from SJF's register of 1,500 individuals in 1989 (response rate 59\%), 2,000 individuals in 2005 (response rate 59\%) and 2,500 individuals in 2011 (response rate 60\%). The representativeness is generally good for all the surveys.

The studies were carried out by postal surveys in the autumn each year. In all cases, the fieldwork was approximately four months, including several reminders. All surveys contained questions on the view on the journalist's role, opinion and press ethics, and the view on the role of the media in society.

Questions on commercialization in the survey are few. Specifically, there were three questions available all years. One question was very general, which evaluated if working as a journalist has become more or less commercialized for the last 5-10 years. In addition, two questions on specific traits of commercialization were used: If a newspaper that sells well is a good newspaper; correspondingly, if celebrity-oriented journalism has any place in a daily paper or not. Relative to commercialization as a multidimensional concept, this means that the aim cannot be completely satisfied. What we can achieve, however, is a general indicator of changes over time, as well as similarities and differences among journalists. The most interesting figures are thus not single levels of agreement, but comparisons over time and between groups.

To use surveys in a study about attitudes also has, of course, some general limitations. The results must be treated as a kind of attitude overview, with no in-depth knowledge. One must also be aware that the concept of commercialization is problematic and therefore unclear in itself. 


\section{Results}

Despite the diffuseness of the concept of commercialization, and the fact that it can be interpreted in different ways, it can still be used, and most people have some general idea of what it means in everyday language. When the Swedish journalists were asked for their view on whether the journalist's work was more or less commercial 5-10 years ago than it is today, the vast majority had a crystal clear opinion: Yes, it has changed and become more commercialized, and during the last five to six years, it has increased dramatically (Figure 1). The question was posed in 2005 and 2011, but not in 1989 .

Figure 1. The journalists' opinion on the commercialization of work today compared with 5-10 years ago, 2005 and 2011 (per cent).

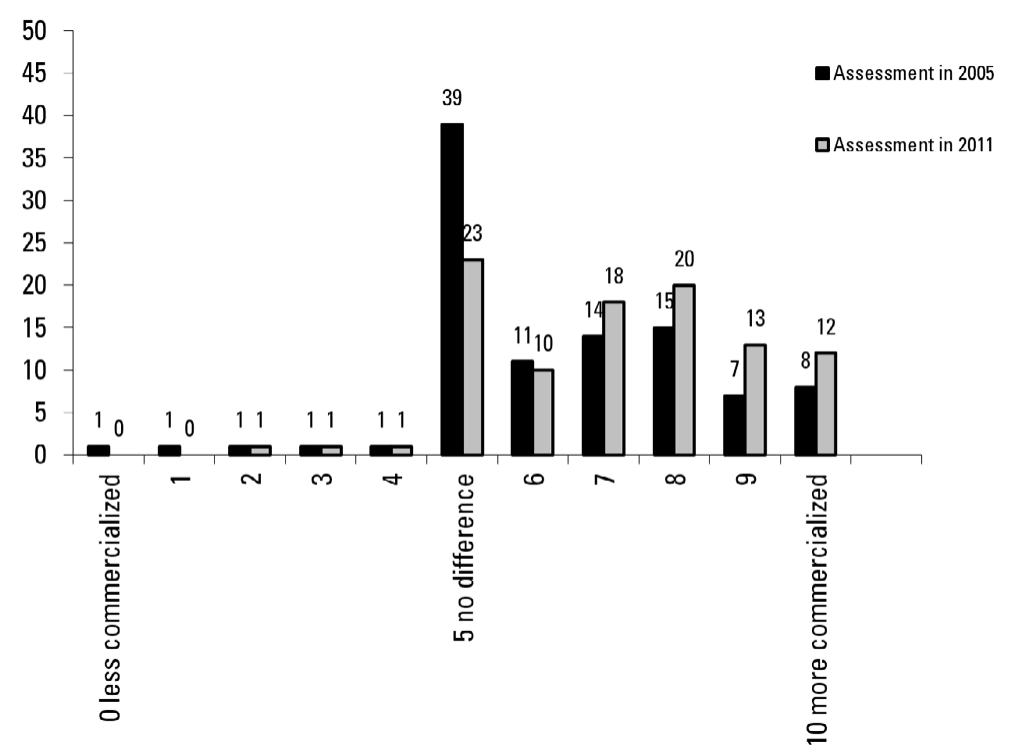

Source: Journalists 2005 and 2011, University of Gothenburg.

The question was: Think about what it was like working as a journalist 5-10 years ago: has the journalistic profession become more or less commercialized?

Comment: The assessment of the commercialization of the work compared with 5-10 years ago is part of a suite of 10 sub-questions. The number of respondents is 854 in 2005 and 1,155 in 2011. 
Table 1. Journalists' assessment if the work has become more commercialized compared to 5-10 years ago, by groups, 2005 and 2011 (mean and eta; number of respondents in parenthesis)

\begin{tabular}{lll}
\hline & Assessment in 2005 & Assessment in 2011 \\
\hline Everyone & $6,39(854)$ & $7,13(1155)$ \\
Gender & & \\
Woman & $6,33(390)$ & $7,22(526)$ \\
Man & $6,45(453)$ & $7,05(589)$ \\
Eta & 0,03 & 0,046 \\
& & \\
Age & & $7,02(81)$ \\
Under 33 years & $6,40(105)$ & $6,96(358)$ \\
33-45 years & $6,35(327)$ & $7,22(673)$ \\
Over 46 years & $6.42(422)$ & 0,066 \\
Eta & 0,016 & \\
& & $7,32(521)$ \\
Ideology & & $7,00(421)$ \\
Left & $6,43(387)$ & $6,85(163)$ \\
Centre & $6,34(340)$ & $0,100^{*}$ \\
Right & $6,41(108)$ & \\
Eta & 0,023 & $6,40(189)$ \\
Workplace & & $6,92(422)$ \\
Public service & $5,74(146)$ & $7,66(110)$ \\
Medium-commercial & $6,25(338)$ & $0,214^{* * *}$ \\
Commercial & $6,82(145)$ & \\
Eta & $0,193^{* * *}$ & \\
\hline
\end{tabular}

Source: Journalists 2005 and 2011, University of Gothenburg.

Comment: For question posed, see Figure 1. Ideology is based on an elevenpoint scale, in which the left has values between $0-3$, the centre 4-6 and the right 7-10. Public service refers to public service radio and TV; a mediumcommercial workplace refers to morning papers and TV4, as these have an ambition to act as public service media, though they are commercially financed; and a commercial workplace refers to the single sold tabloids, periodicals, free dailies, commercially financed radio and TV stations, and production companies. A regression model for 2005 gives ,042 as an adjusted R2 and for 2011,063 . The significance for workplace remains under control for the other independent variables.

${ }^{*} \mathrm{p}<.05^{* *} \mathrm{p}<.01{ }^{* * *} \mathrm{p}<.001$

In principle, no journalist thinks that commercialization has decreased over the last 5-10 years, with regards to the journalistic profession in general. That goes for 2005 as well as for 2011. The majority agrees that work has become more commercialized. If values 6-10 in Figure 1 are added, they total 55 per cent in 2005 and 74 per cent in 2011. A further 40 per cent (2005) believed 
that there was no difference, and that proportion has almost decreased by half in 2011. The change over time is significant.

In 2005, the assessment concerned the situation from the mid and end of the 1990's, when competition grew rapidly, and the Internet developed. In 2011, assessing the situation around the turn of the century, the most marked change of the media market was the growing penetration of broadband in society. The big staff cuts among journalists that have characterized the last few years in Sweden, started in 2011, and it is reasonable to believe that the journalists, at least to some extent, had this in mind, when they answered the question in 2011.

An analysis of the views of different groups of journalists then indicates that traditional background factors such as gender, age and ideological views do not play a part in their opinions, neither in 2005, nor in 2011. In contrast, the type of company, for which they work, does play a part (Table 1).

Those who work in the media that are generally considered the most commercial - the evening press, commercial TV etc. - are the ones who consider the work more commercial than before. We see the same patterns in both years, but at a higher level in 2011. It is worth noting that the change is greater among journalists working in a commercial workplace, than among journalists working in public service or medium-commercial workplaces.

Allowing the journalists to make a retroactive assessment of how the work situation has changed is one way of studying changes, but it is not the only one. It was also a loosely formulated question, with no definition of what more or less commercialized work means. Asking questions on repeated occasions is another option for comparison over time. We will continue with the two other survey questions concerning commercialization.

Two specific questions were asked in the Swedish journalist surveys in 1989, 2005 and 2011 that can be seen as indicators of the views of journalists on commercialization at different levels (Figure 2). If we follow the categorization of the concept of commercialization made in the introduction, the first-mentioned question can be said to be at market level, whereas the second is at content level. The assertions that are used as indicators of the view on commercialization are in no way exhaustive, and should only be seen as indicators. 
The assumption that a newspaper that sells well is a good newspaper, is an aspect of the role of the media in the market. The mean is 3 at a 4-level scale, on which 1 corresponds to 'agree' and 4 to 'disagree', which implies that the journalists, to a large extent, disagree in the statement. The most interesting point, however, is not the level of agreement, but that we see no change over time. Due to changes in the media system as well as in society in general, in the direction that journalism has become more of a common product than ever before, one could have expected at least some change in journalists' opinion-but there are none.

The extent of celebrity-oriented journalism is intended to work as a measure of acceptance of commercial content. Mean is around 2 on the same 4 -level scale. It is thus a larger proportion of the journalists, who agree on this subject compared to the subject above. Further, there is an increased share of disagree-

Figure 2. Journalists' opinion on two aspects of commercialization, 1989, 2005 and 2011 (mean)

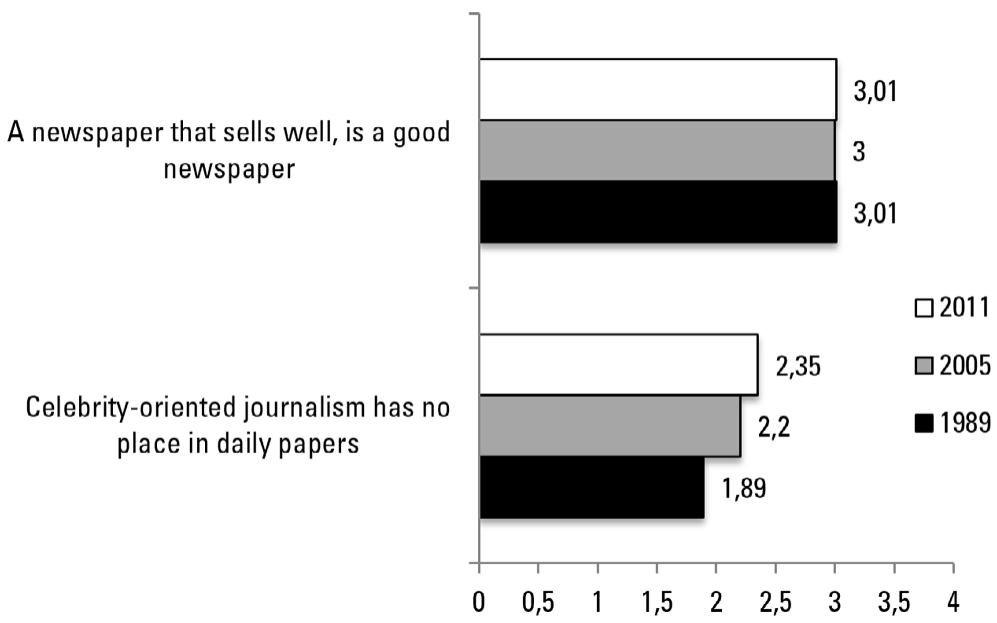

Source: Journalists 1989, 2005 and 2011, University of Gothenburg.

The question read: What is your opinion on the following assertions about mass media and journalism? Both of the above assertions are part of a suite of ten sub-questions of different characters. The answer option was fourfold: 'completely agree' (1), 'partly agree', 'partly disagree' and 'totally disagree' (4). Comment: The number of respondents is between 823/827 in 1989, 1,039/1,045 in 2005 , and 1,317/1,342 in 2011. Differences in mean is staitstic significant for the second item, but nor for the first. 
ment of the negative assertion that celebrity-oriented journalism had no place in daily papers over time, i.e. an increasing acceptance of this kind of material over time. The change over time is in this case, statistically significant.

So, do the journalists agree as a group on both these assertions to the same extent, as they do on the general commercialization of the work, despite differences related to workplace? Table 2 displays the values for different journalist groups.

Table 2. Journalists' opinion on two aspects of commercialization, by groups, 1989, 2005 and 2011 (mean and eta; number of respondents in parenthesis)

\begin{tabular}{|c|c|c|c|c|c|c|}
\hline & \multicolumn{3}{|c|}{$\begin{array}{l}\text { A newspaper that sells well, is a } \\
\text { good newspaper }\end{array}$} & \multicolumn{3}{|c|}{$\begin{array}{l}\text { Celebrity-oriented journalism has } \\
\text { no place in daily papers }\end{array}$} \\
\hline & 1989 & 2005 & 2011 & 1989 & 2005 & 2011 \\
\hline Everyone & $3,01(823)$ & 3,00 (1039) & 3,01 (1317) & $1,89(827)$ & 2,20 (1045) & 2,35 (1342) \\
\hline \multicolumn{7}{|l|}{ Gender } \\
\hline Woman & $3,18(284)$ & $3,00(521)$ & $3,13(656)$ & $1,70(285)$ & 2,08 (521) & $2,29(663)$ \\
\hline Man & 2,92 (535) & $2,90(508)$ & $2,89(661)$ & $2,00(538)$ & 2,32 (514) & $2,41(679)$ \\
\hline Eta &, $151^{* * *}$ &, $130 * * *$ &, $155^{* * *}$ &, $151^{* * *}$ &, $121^{* * *}$ &, $070^{* * *}$ \\
\hline \multicolumn{7}{|l|}{ Age } \\
\hline Under 33 years & $3,17(206)$ & 3,07 (269) & $3,10(273)$ & 1,90 (209) & $2,30(266)$ & $2,49(274)$ \\
\hline $33-45$ years & $3,05(367)$ & $2,97(357)$ & 3,00 (395) & $1,88(365)$ & 2,26 (359) & $2,39(398)$ \\
\hline Over 46 years & 2,81 (249) & $2,99(413)$ & 2,99 (645) & 1,91 (252) & $2,09(420)$ & $2,26(666)$ \\
\hline Eta &, $170^{* * *}$ & ,055 & ,057 & , 017 & ,099 &, $100^{* * *}$ \\
\hline \multicolumn{7}{|l|}{ Ideology } \\
\hline Left & $3,18(324)$ & 3,08 (469) & $3,15(630)$ & $1,79(324)$ & 2,12 (477) & $2,28(645)$ \\
\hline Centre & 2,94 (368) & 2,98 (418) & $2,96(478)$ & $1,95(373)$ & 2,24 (419) & 2,37 (489) \\
\hline Right & 2,66 (107) & $2,80(138)$ & 2,71 (197) & 2,01 (108) & 2,37 (135) & 2,49 (194) \\
\hline Eta &, $213^{* * *}$ &, $118^{* * *}$ &, $200^{* * *}$ & ,093 &, $089 * * *$ &, $082^{* * *}$ \\
\hline \multicolumn{7}{|l|}{ Workplace } \\
\hline Public service & 3,14 (103) & $3,21(188)$ & $3,22(214)$ & $1,88(102)$ & 2,07 (189) & $2,30(212)$ \\
\hline Medium-com- & $2,93(389)$ & $2,84(376)$ & $2,83(466)$ & $1,83(2,44)$ & $2,27(383)$ & $2,40(486)$ \\
\hline mercia & & & & & & \\
\hline Commercial & 2,69 (99) & $2,94(173)$ & 2,96 (158) & 2,44 (101) & $2,47(170)$ & $2,81(156)$ \\
\hline Eta & $159 * * *$ &, $191^{* * *}$ &, $217^{* * *}$ &, $234^{* * *}$ &, $148^{* * *}$ &, $197^{* * *}$ \\
\hline
\end{tabular}

Source: Journalists 1989, 2005 and 2011, University of Gothenburg.

Comment: For the questions and answers posed, see Figure 2. For definitions, see Table 1. The significance remains for the independent variables in a regression model for the first question (a newspaper that sells ...), but the second question (celebrity-oriented journalism ...) doesn't show significance of ideology in 2005 , and in 2011, only workplace is significant in the regression.

${ }^{*} p<.05{ }^{* *} p<.01{ }^{* * *}<.001$ 
The interesting results are the differences between groups rather than changes over time. One of the subjects show significance over time on an aggregated level, but changes in different groups over time are not significant. Several differences among journalist groups are, however, significant.

Most interesting is, once again, the workplace of the journalists. These results are significant, both in eta and logistic regression, for both subjects. When working in a commercial workplace, journalists agree to a higher extent that a newspaper that sells well, is a good newspaper, and they agree to a lower extent on the statement that celebrity-oriented journalism has no place in daily papers. For both subjects, the same patterns can be found, when it comes to ideology, in which case right-wing journalists display the same views as journalists working in commercial workplaces. The same pattern also applies to men in relation to women. When it comes to age, there are no significant differences between young and old over time.

The results indicate that, even if the questions concern a trait of commercialization on market level or content level, the opinions move in the same direction. If a journalist is, if not positive, then at least more positive than others towards the fact that a newspaper should sell well, then the journalist is likely to accept celebrity-oriented journalism to a larger extent, too.

\section{Conclusion}

In this study, commercialization as a phenomenon has been studied through three empirical questions that cover certain aspects of commercialization, but far from the whole concept. The first survey question is retrospective; if the journalists find that their work has become more commercialized over time. The second and third questions from the survey are indicators of journalists' opinions on a commercialized content, correspondingly journalism as a product in the market.

So, what is the journalists' opinion on commercialization, and do we see a change over time of their opinion? This is the first research question. The opinion on commercialization is, by and large, negative. The general opinion is also that commer- 
cialization has increased over time. Small changes in journalists' opinions over time can be found in the material. Therefore, the answer to the first research question must be that the opinion on commercialization is rather negative and stable, and to some extent increase over time.

The second research question is, if the journalists can be regarded as a homogenous group or, if not, what may explain the journalists' opinions on commercialization. There are no dramatic differences between groups of journalists. Rather, the journalists can be said to be fairly unanimous in their views on the aspects of commercialization that have been subject to analysis here. It is, however, worth noting the differences in opinion based on the workplace of journalists. Journalists working in commercial workplaces - single sold tabloids, commercially financed television, periodicals etc. - have a more positive (or, rather, less negative) attitude towards commercialization. On the other hand, they are also of the opinion that the work has become more commercialized over time. It seems, though, that they also show a greater acceptance of the commercialization, despite the belief that the work has become more commercialized,

The relatively minor differences with regards to social identity among different groups suggest that the journalists are a fairly homogenous group, when it comes to their views on commercialization - also over time. The most logic explanatory factor for journalists' view on commercialization thus seems to be the journalistic profession, not individual factors. The journalists share a strong and professional ideology (Deuze, 2005), and we know that the ideals of the Swedish journalists are almost unanimous (Wiik, 2010). It is therefore reasonable to assume that they form a group that probably also wants to be homogenous, in the sense that they want to be part of a psychological community with their colleagues. It may even be suggested that they work as a kind of socialization agent for each other - for good and for bad (cf. Donsbach, 2004; Fengler and Russ-Mohl, 2008). They then make the same assessments, maybe above all, on controversial issues, on which they ought to think in a certain way. They ought not to be too positive about commercialization. They ought to consider that the work has become more commercial. Even if the survey questions applied in this study are not comprehensive, 
we can be fairly sure that journalists do care about commercialization.

\section{REFERENCES}

Andersson, Ulrika (2009). Journalister och deras publik [Journalists and Their Audience]. Gothenburg: Dept. of Journalism, Media and Communication, University of Gothenburg.

Andersson, Ulrika (2012). "Metoddokumentation” [Methodological Section], pp. 117-126 in Kent Asp (ed.), Svenska journalister 1989-2011 [Swedish Journalists 1989-2011]. Gothenburg: Dept. of Journalism, Media and Communication, University of Gothenburg.

Asp, Kent (2007). “Åsikter och ideologier” [Opinions and Ideologies], pp. 207-220 in Kent Asp (ed.), Den svenska journalistkåren [The Swedish Journalists]. Gothenburg: Dept. of Journalism, Media and Communication, University of Gothenburg.

Asp, Kent (ed.) (2012). Svenska journalister 1989-2011. [Swedish Journalists 1989-2011]. Gothenburg: Dept. of Journalism, Media and Communication, University of Gothenburg.

Baldasty, Gerald J. (1992). The Commercialization of News in the Nineteenth Century. Madison and London: The University of Wisconsin Press.

Beam, Randal A. (2003). "Content Differences between Daily Newspapers with Strong and Weak Market Orientations", Journalism \& Mass Communication Quarterly, 80 Volume, No. 2, pp. 368-390.

Berkowitz, Dan (2007). "Professional Views, Community News: Investigative Reporting in Small US Dailies”, Journalism, 8 Volume, No. 5, pp. 551-558.

Bodén, Bosse and Lennart Rosenberg (2004). Kommersiell turism och lokal samhällsutveckling. En studie av sex svenska fjälldestinationer [Commercial Tourism and Local Development. A Study of Six Swedish Mountain Destinations]. Östersund: European Tourism Research Institute.

Bok, Derek (2003). Universities in the Marketplace. The Commercialization of Higher Education. Princeton and Oxford: Princeton University Press.

Croteau, David and William Hoynes (2006). The Business of Media. Corporate Media and the Public Interest. Thousand Oaks, London, New Delhi: Pine Forge Press. 
Deuze, Mark (2005). "What is Journalism? Professional Identity and Ideology of Journalist Reconsidered”. Journalism, 6 Volume, No. 4, pp. 442-464.

Djerf-Pierre, Monika (2000). "Squaring the Circle: Public Service and Commercial News on Swedish Television 1956-99”. Journalism Studies, 1 Volume, No. 2, pp. 239-260.

Donsbach, Wolfgang (2004). "Psychology of News Decisions. Factors Behind Journalists' Professional Behaviour”. Journalism, 5 Volume, No. 2, pp. 131-157.

Fengler, Susanne and Russ-Mohl, Stephan (2008). "Journalists and the Information-Attention Markets”. Journalism, 9 Volume, No. 6, pp. 667-690.

Giddens, Anthony (2009). Sociology. Cambridge: Polity Press.

Hallin, Daniel C. and Mancini, Paolo (2004). Comparing Media Systems: Three Models of Media and Politics. Cambridge \& New York: Cambridge University Press.

Hamilton, James T. (2006). All the News That's Fit to Sell. How the Market Transforms Information into News. Princeton and Oxford: Princeton University Press.

Hanitzsch, Thomas, Folker Hanusch, Claudia Mellado, Maria Anikina, Rosa Berganza, Incilay Cangoz, Mihai Coman et al. (2011). “Mapping Journalism Cultures Across Nations”. Journalism Studies, 12 Volume, No. 3, pp. 273-293.

Hesse-Biber, Sharlene (1996). Am I Thin Enough Yet? The Cult of Thinness and the Commercialization of Identity. New York and Oxford: Oxford University Press.

Hochschild, Arlie Russell (2003). The Commercialization of Intimate Life. Notes from Home and Work. Berkeley, Los Angeles and London: University of California Press.

Jensen, Joli (1998). The Nashville Sound. Authenticity, Commercialization, and Country Music. Nashville and London: The Country Music Foundation Press \& Vanderbilt University Press.

Löfgren Nilsson, Monica (2010). “Thinkings and Doings of Gender Gendering Processes in Swedish Television News Production”. Journalism Practice, 4 Volume, No. 1, pp. 1-16.

McAllister, Matthew (1996). The Commercialization of American Culture. New Advertising, Control and Democracy. Thousand Oaks, London and New Delhi: Sage.

McManus, John H. (1994). Market Driven Journalism. Let the Citizen 
Beware?. Thousand Oaks, London and New Delhi: Sage.

McQuail, Denis (1985). “Commercialization”. In: Denis McQuail and Karen Siune (eds.), New Media Politics. Comparative Perspectives in Western Europe. London, Beverly Hills and New Delhi: Sage.

McQuail, Denis (2005). McQuail's Mass Communication Theory. London, Thousand Oaks and New Delhi: Sage.

Molnar, Alex (1996). Giving Kids the Business. The Commercialization of America's Schools. Boulder and Oxford: Westview Press.

Nygren, Gunnar (2008). Nyhetsfabriken. Journalistiska yrkesroller $i$ en förändrad medievärld [The News Factory. Professional Journalist Roles in a Changing Media World]. Lund: Studentlitteratur.

O’Neill, Deidre and O'Connor, Catherine (2008). “The Passive Journalist. How Sources Dominate Local News", Journalism Practice, 2 Volume, No. 3, pp. 487-500.

Ottosen, Rune (2004). I journalistikkens grenseland. Journalistrollen mellom marked og idealer [In the Borderland of Journalism. The Journalists Between Markets and Ideals]. Fredrikstad: IJ-forlaget.

Papathanassopoulos, Stylianos (2001). "Media Commercialization and Journalism in Greece", European Journal of Communication, 16 Volume, No. 4, pp. 505-521.

Picard, Robert G. (2005). "Money, Media and the Public Interest”, pp. 337-350 in Geneva Overholser and Kathleen Hall Jamieson (eds.), The Institutions of Democracy: The Press. Oxford: Oxford University Press. Picard, Robert G. (2008). "The Challenge of Public Functions and Commercialized Media”, pp. 211-229 in Doris A. Graber, Denis McQuail and Pippa Norris (eds.), The Politics of News. The News of Politics. Washington: CQ Press.

Plasser, Fritz (2005). "From Hard to Soft News Standards? How Political Journalists in Different Media Systems Evaluate the Shifting Quality of News", The Harvard International Journal of Press/Politics, 10 Volume, No. 2, pp. 47-68.

Rolland, Asle (2006). "Commercial News Criteria and Investigative Journalism”, Journalism Studies, 7 Volume, No. 6, pp. 940-963.

Singer, Jane B. (2003). "Who Are These Guys? The Online Challenge to the Notion of Journalistic Professionalism”, Journalism, 4 Volume, No. 2, pp. 139-163.

Strömbäck, Jesper (2007). "Political Marketing and Professionalized Campaigning”, Journal of Political Marketing, 6 Volume, No. 2, pp. 49-67. 
Sylwan, Otto (1906). Den moderna pressen. Dess uppkomst och utveckling intill våra dagar [The Modern Press. Its Emergence and Development until Today]. Stockholm: Bonniers.

Thore, Sten A. (ed.) (2002). Technology Commercialization: DEA and Related Analytical Methods for Evaluating the Use and Implementation of Technical Innovations. Norwell and Dordrecht: Kluwer Academic Publishers.

Wadbring, Ingela (2013). "Levels of Commercialization”, pp. 119-134 in Manuel Puppis, Matthias Künzler \& Otfried Jarren (eds.), Media Structures and Media Performance. Wien: Verlag der Österreichische Akademie der Wissenschaften.

Wiik, Jenny (2010). Journalism in Transition. The Professional Identity of Swedish Journalists. Gothenburg: Dept. of Journalism, Media and Communication, University of Gothenburg.

INGELA WADBRING, PhD, is Professor in media and communication science with specialization in media development. She is currently working at the Section for Media and Communication studies at Mid Sweden University in Sweden. Her research is oriented towards longitudinal changes in media conditions, content, and audience behavior. ingela.wadbring@miun.se 